\title{
Application of molybdenum and a desiccant herbicide to the common bean under direct seeding ${ }^{1}$
}

\author{
Aplicação de molibdênio ao feijoeiro em semeadura direta junto com herbicida \\ dessecante
}

\author{
Gessimar Nunes Camelo² ${ }^{2 *}$, Geraldo Antonio de Andrade Araújo ${ }^{3}$, Renildes Lúcio Ferreira Fontes ${ }^{4}$, Luiz Antonio \\ dos Santos Dias ${ }^{3}$ e José Eustáquio de Souza Carneiro ${ }^{3}$
}

\begin{abstract}
Applying micronutrients together with the herbicides used in plant desiccation can ensure an adequate supply of these nutrients and a reduction in production costs under a direct seeding (DSS) system. The aim of this study was to evaluate the effect of dosages of molybdenum (Mo), applied both in a desiccation operation together with glyphosate on the straw of brachiaria (Brachiaria brizantha) and separately via the leaves, on the common bean (cultivar Ouro Vermelho) grown under DSS. A randomised block design was used with four replications in an arrangement of sublots. In the lots, dosages of Mo $\left(0,0.1,0.2,0.4\right.$ and $\left.0.8 \mathrm{~kg} \mathrm{ha}^{-1}\right)$ were applied together with the desiccant herbicide (glyphosate), and in the sublots, two dosages of Mo $\left(0\right.$ and $\left.100 \mathrm{~g} \mathrm{ha}^{-1}\right)$ were applied via the leaves. Two experiments were carried out in the town of Coimbra, in the state of Minas Gerais, Brazil, one in 2009 and the other in 2010 (the same treatments having been applied in the experimental area in 2008). Foliar fertilization was carried out with sodium molybdate $\left[\left(\mathrm{Na}_{2} \mathrm{MoO}_{4}\right)(39 \% \mathrm{Mo})\right]$ at stage V4 in the bean plants. The application of Mo, whether mixed with the desiccant or applied via the leaves, had no significant effect on yield components or on productivity. Levels of Mo and $\mathrm{N}$ in the grain, and of $\mathrm{N}$ in the leaves, increased with the application of Mo, both when mixed with the desiccant and applied via the leaves.
\end{abstract}

Key words: Brachiaria Brizantha. Desiccant herbicide. Nitrogen. Phaseolus vulgaris L..

RESUMO - A aplicação de micronutrientes juntamente com herbicidas em dessecação de plantas pode garantir o suprimento adequado desses nutrientes, com diminuição nos custos de produção no sistema de semeadura direta (SSD). Objetivou-se com este trabalho avaliar o efeito de doses de molibdênio (Mo), aplicado em operação de dessecação, junto ao glifosato, sobre a palhada de braquiária (Brachiaria brizantha), e isolado, por via foliar, em feijoeiro (cultivar Ouro Vermelho) cultivado no SSD. Utilizou-se o delineamento em blocos casualizados, com quatro repetições, no esquema de parcelas subdivididas. Nas parcelas, foram aplicadas doses de Mo $\left(0 ; 0,1 ; 0,2 ; 0,4\right.$ e $\left.0,8 \mathrm{~kg} \mathrm{ha}^{-1}\right)$, juntamente com herbicida dessecante (Glifosato) e, nas subparcelas, duas doses de Mo (0 e $\left.100 \mathrm{~g} \mathrm{ha}^{-1}\right)$, por via foliar. Foram realizados dois experimentos no município de Coimbra, Estado de Minas Gerais, um no ano de 2009 e outro em 2010 (em 2008, os mesmos tratamentos haviam sido aplicados na área experimental). A adubação foliar foi feita com molibdato de sódio $\left(\left(\mathrm{Na}_{2} \mathrm{MoO}_{4}\right)(39 \%\right.$ de Mo)), no estádio V4 do feijoeiro. A aplicação do Mo, tanto na mistura com o dessecante como por via foliar, não causou efeito significativo sobre os componentes de produção e sobre a produtividade. Os teores de Mo e $\mathrm{N}$ nos grãos e de $\mathrm{N}$ nas folhas aumentaram com a aplicação do Mo, tanto em mistura com o dessecante como por via foliar.

Palavras-chave: Brachiaria brizantha. Herbicida dissecante. Nitrogênio. Phaseolus vulgaris L..

\footnotetext{
DOI: $10.5935 / 1806-6690.20150040$

*Autor para correspondência

'Recebido para publicação em 16/09/2012; aprovado em 19/03/2015

Part of Master's Dissertation of the first author, submitted to the Graduate Program in Plant Science of the Universidade Federal de Viçosa. Trabalho financiado pelo CNPq e FAPEMIG

${ }^{2}$ Agronomist Engineer, Doctor of Science, Postdoctoral/PNPD/CAPES, Seed laboratory of the Instituto Federal Goiano, Câmpus Rio Verde, Rod. Sul Goiana Km 01, Zona Rural, 75901-970, Rio Verde, Goiás, Brazil, gessimarcamelo@ yahoo.com.br

${ }^{3}$ Departamento de Fitotecnia/Agronomist Engineer, Doctor of Science/Universidade Federal de Viçosa, Campus Viçosa, Avenida Peter Henry Rolfs, s/n, Viçosa-MG, Brazil, 36.570-000, garaujo@ufv.br, lasdias@ufv.br, eustaquiocarneiro@yahoo.com.br

${ }^{4}$ Departamento de Solos/Agronomist engineer/Ph.D., Universidade Federal de Viçosa, Campus Viçosa, Avenida Peter Henry Rolfs, s/n, ViçosaMG, Brazil, 36.570-000, renildes@ufv.br
} 


\section{INTRODUCTION}

The common bean is grown by small and large producers in all regions of Brazil, and as such is both economically and socially representative. Despite a symbiotic association with rhizobia for the fixation of molecular nitrogen $\left(\mathrm{N}_{2}\right)$, cultivation of the bean depends on additional fertilization with nitrogen in order to achieve any significant productivity.

Nitrogen $(\mathrm{N})$ is the nutrient that is most absorbed by bean plants. Currently, dosages greater than $100 \mathrm{~kg} \mathrm{~N} \mathrm{ha}^{-1}$ are becoming common in high-yield crops. The great importance of molybdenum (Mo) for plants, especially the Fabaceae (legumes), lies in its direct relationship with the enzymes related to the metabolism of N (SCHWARZ; MENDEL; RIBBE, 2009). For the enzyme nitrogenase, responsible for the symbiotic fixation of atmospheric $\mathrm{N}_{2}$ and the production of $\mathrm{NH}_{3}$ in a reaction mediated by Rhizobium, the Mo participates as a structural element. The same occurs for nitrate reductase, an enzyme which catalyses the reduction of $\mathrm{NO}_{3}^{-}$to $\mathrm{NO}_{2}^{-}$, the first step in incorporating $\mathrm{N}$ into organic molecules (MARSCHNER, 1995). When plants that are dependent on symbiosis are grown in soil that is low in the micronutrient, they display this lack by symptoms characteristic of $\mathrm{N}$ deficiency (DECHEN; NACHTIGALL, 2007). Several factors can affect the availability of Mo in the soil, including the $\mathrm{pH}$, organic matter, texture, drainage, iron and aluminium oxides, redox potential and interaction with other nutrients (FERREIRA et al., 2003).

The success of the direct seeding system (DSS) is dependent on the quantity, quality and permanence of mulch on the surface of the soil. These conditions are met by species of plants from the genus Brachiaria, which stand out due to their active and continuous root growth, high capacity for biomass production, nutrient recycling and soil preservation.

Although there is no standard response to Mo for a bean crop under field conditions, an increase in bean yield due to Mo being supplied via the leaves has been noted in several studies (ALBUQUERQUE et al., 2012; ARAÚJO et al., 2009; ASCOLI et al., 2008; CALONEGO et al., 2010; LEITE et al., 2007; PIRES et al., 2004). Araújo et al. (2008) demonstrated the feasibility of applying a mixture of Mo to pesticide sprays during the V4 stage of the bean, with the aim of reducing costs and rationalising the use of equipment. In 2008, using the same area as in the present experiment, Damato Neto (2010) obtained an increase in bean yield in the first year of cultivation, after the application of Mo together with the desiccant glyphosate to brachiaria straw under DSS.

Despite evidence that bean plants may be capable of absorbing Mo applied on straw together with a desiccant, there is still no information about the behaviour of the crop over the years. Therefore, in 2009 and 2010, the experiment conducted in 2008 by Damato Neto (2010) was repeated. The objective of the present study was to evaluate the effect of dosages of Mo, applied with glyphosate to brachiaria straw in a desiccation operation and separately via foliar application, on bean plants grown under the direct seeding system.

\section{MATERIALS AND METHODS}

The experiments were conducted in the town of Coimbra, in the state of Minas Gerais, Brazil (MG); at coordinates $20^{\circ} 50^{\prime} 30^{\prime \prime} \mathrm{S}$ and $42^{\circ} 48^{\prime} 30^{\prime \prime} \mathrm{W}$, an altitude of approximately $715 \mathrm{~m}$, in soil classified as a dystrophic Red-Yellow Argisol (EMBRAPA, 2006).

In 2009 and 2010, two experiments were carried out on a bean crop cultivated on brachiaria straw (Brachiaria brizantha cv. Marandu) in two areas, which were in their second and third years under direct seeding respectively. The first year was established in 2008 (DAMATO NETO, 2010), when the same treatments were applied in the experimental area, with the exception of fertilization with a nitrogen topdressing. The same locality and sortition for the treatments in the plots were used in both crop years. Sowing of the bean crop took place on 26 March 2009 and 14 April 2010 (autumnwinter season). A randomised block design with four replications was used in a scheme of split lots, with dosages of Mo (0, 0.1, 0.2, 0.4 and $\left.0.8 \mathrm{~kg} \mathrm{ha}^{-1}\right)$ applied together with a desiccant herbicide (glyphosate) to the lots, and dosages of Mo (0 and $\left.100 \mathrm{~g} \mathrm{ha}^{-1}\right)$ applied via the leaves in the sublots in both crop years.

The lots consisted of four rows of bean plants (10 $\mathrm{m}$ in length) spaced $0.5 \mathrm{~m}$ apart and divided into sublots $5 \mathrm{~m}$ in length. The two central rows of each sublot was considered as the usable area $\left(4 \mathrm{~m}^{2}\right)$, excluding $0.5 \mathrm{~m}$ from each end. Sowing was carried out using a planter equipped with an out-of-phase, twin-disc mechanism. The seeding rate was 15 seeds $\mathrm{m}^{-1}$ of row. Prior to application of the treatments in the first seeding (2008), soil samples were collected at a depth of $0-20 \mathrm{~cm}$, and the chemical properties of the soil were characterised (Table 1). Immediately after sowing, samples of brachiaria straw were collected from each sublot to evaluate the dry matter weight, employing a quadrat square method with a metal frame of $0.15 \mathrm{~m}$ x $0.40 \mathrm{~m}\left(0.10 \mathrm{~m}^{2}\right)$. The collected samples were dried to constant weight in a forced circulation oven at $70{ }^{\circ} \mathrm{C}$. The dry matter weight of the straw for 2009 and 2010 was 17.8 and $13.7 \mathrm{t} \mathrm{ha}^{-1}$ respectively.

The cultivar used was Ouro Vermelho, of indeterminate growth (a type II/III plant), semi-erect and with an 80-90 day cycle, part of the red commercial marketing group. In 2009 , thirty days before desiccation of the brachiaria straw, the area was mown to leave it uniform. This was not done in 2010, as the previous year had shown that this operation made it difficult to maintain straw in the lot. In both years, 
Table 1 - Chemical characteristics* of the soil in the 0 to $20 \mathrm{~cm}$ layer

\begin{tabular}{|c|c|c|c|c|c|c|c|c|c|c|c|c|}
\hline $\mathrm{pH}$ & $\mathrm{P}$ & $\mathrm{K}^{+}$ & $\mathrm{H}^{+} \mathrm{Al}$ & $\mathrm{Al}^{3+}$ & $\mathrm{Ca}^{2+}$ & $\mathrm{Mg}^{2+}$ & $\mathrm{CEC}_{\text {total }}$ & $\mathrm{CEC}_{\text {effective }}$ & SB & V & M & P-rem \\
\hline $\mathrm{H}_{2} \mathrm{O}$ & \multicolumn{2}{|c|}{$\mathrm{mg} \mathrm{dm}{ }^{-3}$} & -----. & ---- & ---- & $\mathrm{cmol}_{\mathrm{c}}$ & -3 & & ------ & \multicolumn{2}{|c|}{------- \% ------- } & $\mathrm{mg} \mathrm{L}^{-1}$ \\
\hline 6.1 & 8.3 & 84 & 3.3 & 0.0 & 2.6 & 1.0 & 7.1 & 3.8 & 3.8 & 54 & 0.0 & 30.1 \\
\hline
\end{tabular}

*P and K - Extractant: Mehlich 1; Ca, Mg e Al - Extractant: $\mathrm{KCl} 1 \mathrm{~mol} \mathrm{~L}{ }^{-1} ; \mathrm{H}+\mathrm{Al}-$ Extractant: Calcium acetate 0,5 mol L-1 $, \mathrm{pH} 7,0$

desiccation of the brachiaria plants took place 13 days before sowing, using the herbicide glyphosate $\left(1,440 \mathrm{~g}\right.$ a.i. ha $\left.{ }^{-1}\right)$ applied mixed with the dosages of Mo (sodium molybdate $\left(\mathrm{Na}_{2} \mathrm{MoO}_{4}\right)$ with $\left.39 \% \mathrm{Mo}\right)$ as per the above-mentioned treatments. Application was carried out by means of a spray with $\mathrm{CO}_{2}$ under constant pressure (2 bar), using TT 11002 flat fan nozzles spaced $50 \mathrm{~cm}$ apart and at a flow rate of $140 \mathrm{~L} \mathrm{ha}^{-1}$. When sowing, $350 \mathrm{~kg} \mathrm{ha}^{-1}$ of 8-28-16 formula $\left(\mathrm{N}-\mathrm{P}_{2} \mathrm{O}_{5}-\mathrm{K}_{2} \mathrm{O}\right)$ were applied to the row as fertilizer. Foliar fertilization was carried out on the bean plants at stage V4, spraying $180 \mathrm{~L}$ sodium molybdate $\mathrm{h}^{-1}$, using a knapsack sprayer with a cone nozzle and pressure regulating valve. In both experiments, a topdressing of nitrogen was applied manually 28 days after seedling emergence (DAE) to the surface of the soil near the sowing row, applying $45 \mathrm{~kg} \mathrm{~N}$ $\mathrm{ha}^{-1}$ in the form of urea. After application of the nitrogen topdressing, $10 \mathrm{~mm}$ of water was applied in irrigation in order to minimize the loss of $\mathrm{N}$ through volatilization.

In both years, weeds in the bean crop were controlled with a commercial mixture of the herbicides fluazifop-pbutyl and fomesafen (200 and $250 \mathrm{~g} \mathrm{~L}^{-1}$ respectively) at a commercial dosage of $0.8 \mathrm{~L} \mathrm{ha}^{-1}$. When necessary, the plants were sprayed with the fungicide azoxystrobin $\left(120 \mathrm{~g} \mathrm{ha}^{-1}\right)$ to control bean rust (Uromyces appendiculatus (Pers.) Unger) and angular leaf spot (Phaeoisariopsis griseola (Sacc.) Ferraris), and the fungicide Fluazinan to control white mould (Sclerotinia sclerotiorum). Insects were controlled with deltamethrin $\left(80 \mathrm{ml} \mathrm{ha}^{-1}\right)$ whenever the pest population in the field reached moderate levels. The crop was irrigated by conventional sprinkler.

After reaching physiological maturity, the plants in the sublots were harvested and left exposed to the sun to lose moisture. The final stand (plants ha-1), number of pods per plant, number of grains per pod, 100-grain weight and grain yield were all determined. Grain yield $\left(\mathrm{kg} \mathrm{ha}^{-1}\right)$ was calculated from the production data of the usable area of each sublot, and the moisture content standardised on a $13 \%$ wet basis. To analyse the levels of $\mathrm{N}$ and Mo in the leaves for the two years, the third trifoliate, fully developed leaf was collected from the apex of twenty randomly selected bean plants from the usable area of the sublot, between 09:00 and 10:00 at the start of flowering (40 DAE). After harvesting, grain samples were also taken from each treatment to determine the levels of
$\mathrm{N}$ and Mo. The leaf and grain samples were dried in a forced circulation oven at $70{ }^{\circ} \mathrm{C}$ to constant weight. After being ground and homogenised, the samples of leaves and grains were subjected to nitropercloric digestion, and the Mo determined by induced plasma optical emission spectrometry (Perkin Elmer, Model Optima 3300 DV). The levels of foliar $\mathrm{N}$ were obtained by summing the levels of organic-N, determined (after sulphuric digestion) by colorimetry with Nessler's reagent, and the nitrate-N levels. The level of $\mathrm{N}$ in the grains was determined by the semimicro Kjeldahl method, following methodologies described by Malavolta, Vitti and Oliveira (1997).

Statistical analysis was performed by means of both individual and joint variance analysis of the data, using the SAS statistical software (SAS, 2003). For the quantitative factors, models were chosen based on the significance of the regression coefficient, using the t-test at $5 \%$ probability, and the coefficient of determination $\left(\mathrm{R}^{2}=\right.$ regression $\mathrm{SS} /$ treatment SS) and taking into consideration the inherent characteristics of the biological phenomenon under study.

\section{RESULTS AND DISCUSSION}

There was a significant difference between mean values (over two years) for final stand (FS) as a function of the dosages of Mo applied together with the glyphosate $(\mathrm{P}<0.05)$. The exponential model was the best fit to the data (Figure 1). There are no reports in the literature of the depressant effect of Mo on FS in the bean, and so it is believed that this result could not have been caused by the application of the Mo dosages together with the glyphosate. Leite et al. (2007), applying dosages of from 0 to $2.56 \mathrm{~kg} \mathrm{Mo} \mathrm{ha}^{-1}$, and Vieira et al. (2010), applying dosages from 0 to $4.00 \mathrm{~kg} \mathrm{Mo} \mathrm{ha}^{-1}$ via the leaves in the bean, also found no decrease in FS or symptoms of toxicity in the plants.

It should be noted that for the two years, the average dry matter weight of the brachiaria straw was $15.7 \mathrm{t} \mathrm{ha}^{-1}$, which is more than twice the minimum quantity needed under DSS (6 t ha-1) according to Nunes et al. (2006). This probably contributed to the average number of plants in the FS of the experiments, 151,812 plants ha ${ }^{-1}$, being lower than that considered ideal for the bean crop (between 200,000 
and 300,000 plants $\mathrm{ha}^{-1}$ ). The low average number of plants in the FS (Figure 1) can be explained by the high volume of straw in the area over the two years, added to the fact that the area was not mown before desiccation in 2010. At the time of sowing therefore the straw was not completely dry, which contributed to the plants being squashed and not being cut by the planter disc; some seeds remained inside this mass of plants, and had no contact with the ground to initiate the germination process, damaging establishment of the crop.

For the interaction between the foliar Mo dosage and the year of the trial, there was no difference in FS in any one year when comparing whether Mo was added or not (Table 2). Between the years however, and regardless of the application of Mo, the number of plants in the FS was greater in 2009 than in 2010 (Table 2). This was probably because, although the dry matter weight of the straw displayed an average of $17.8 \mathrm{t} \mathrm{ha}^{-1}$ in 2009 , higher than in 2010 (13.7 $\left.\mathrm{t} \mathrm{ha}^{-1}\right)$, the straw in 2009 had been mown 30 days before desiccation, providing better conditions for the establishment of the crop.

Figure 1 - Final stand of a bean crop grown on brachiaria straw as a function of the application of dosages of Mo mixed with the desiccant glyphosate in 2009 and 2010, Coimbra, MG

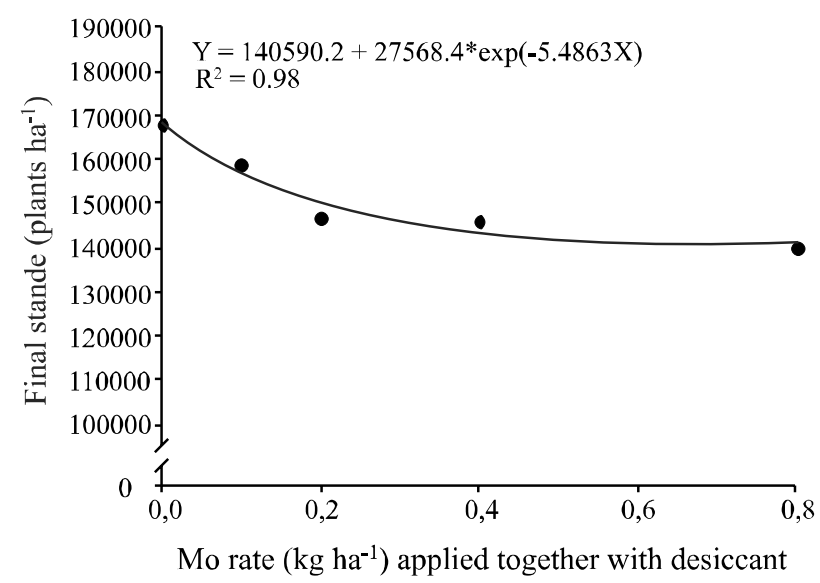

*Significant at $1 \%$
The number of pods per plant (PPP) was not affected by the treatments, with an average value of 9.99 units. Ascoli et al. (2008) evaluated the effect of the dosages and application times of Mo to the leaves of bean plants, also finding no difference in PPP. However, this result disagrees with those obtained by several authors (ARAÚJO et al., 2009; LEITE et al., 2007; PIRES et al., 2004), in tests carried out in the Zona da Mata region of the state of Minas Gerais.

The number of grains per pod (GPP) and the 100-grain weight (W100G) were significantly different when comparing the years (Table 3), with the GPP being greater in 2010 when plant density was lower (Table 2). Production components depend on factors such as plant density, some possibly increasing and others decreasing, contributing to the stability of production (CASQUERO et al., 2006).

There was no effect on grain yield (GY) in the bean plants from the Mo dosages applied together with the glyphosate $(\mathrm{P}<0.05)$. This lack of response was probably due to a $\mathrm{pH}$ of 6.1 in the soil of the experimental area (Table 1), which may have contributed to the Mo and $\mathrm{N}$ being taken up at the required levels, even in those treatments with no added $\mathrm{Mo}$, as increasing the $\mathrm{pH}$ of the soil from 5.4 to 6.4 , can increase leaf concentrations of Mo by $500 \%$ (DECHEN; NACHTIGALL, 2007). This result differs from that found by Damato Neto (2010) in this same area and in the first year of planting (2008), who applied the same treatments with the exception of the application of $\mathrm{N}$ as topdressing, and found an increase of $14 \%$ when comparing the estimated maximum yield from $311 \mathrm{~g} \mathrm{Mo} \mathrm{ha}^{-1}$ to that of the control where no Mo was mixed with the desiccant.

Grain yield differed significantly between the two crop years, being lower in 2010 (Table 3). This was probably due to the lower plant population in 2010 (Table 2). This relation of FS to grain yield differs in the literature, being dependent on the size of the reduction in the stand. Authors such as Ribeiro et al. (2004) state that the FS does not affect yield in the bean crop, while Piana, Silva and Antunes (2007) remark that the yield can be affected by variations in the final plant population. Another explanation was the

Table 2 - Breakdown of the significant interactions in variance analysis, for the final stand of a bean crop grown on brachiaria straw in 2009 and 2010, Coimbra, MG

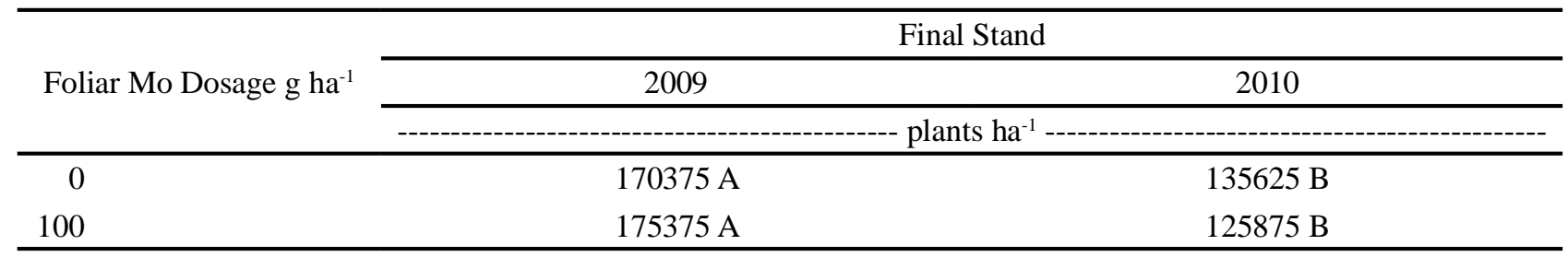

Mean values accompanied by the same uppercase letter on a line do not differ statistically by F-test 
shading caused by the presence of standing brachiaria straw, which had not been mown in 2010 , promoting etiolation in the bean plants and a consequent reduction in the initial development of the crop that year.

The foliar levels of Mo from those lots that did not receive an application of Mo together with the desiccant was equal to $0.73 \mathrm{mg} \mathrm{kg}^{-1}$ (Figure 2). This value is greater than the $0.55 \mathrm{mg} \mathrm{kg}^{-1}$ below which Pessoa et al. (2000) observed Mo deficiency in bean plants, and within the sufficiency range of between 0.40 and $1.40 \mathrm{mg} \mathrm{kg}^{-1}$ proposed by Oliveira and Thung (1988). The results explain why there was no limitation to plant growth even in those treatments where no Mo was added, and no responses seen in the GY of the bean plants to the dosages of Mo applied together with the glyphosate.

The Mo levels in the leaves of the bean plants (LMoL) for the treatment of $100 \mathrm{~g} \mathrm{Mo} \mathrm{ha}^{-1}$ applied via the leaves, were higher than for the treatment with no application of Mo (Table 4).

It was also found that the foliar application of Mo resulted in greater values for LMOL in 2010 compared to 2009 (Table 4), which was probably due to the cumulative effect of Mo having been applied in treatments in the same plots over the previous three years.

The application of Mo together with the glyphosate caused an increase in the levels of $\mathrm{N}$ in the leaves of the bean plants (LNL), with the maximum value being equal to $49.5 \mathrm{~g} \mathrm{~kg}^{-1}$ for an estimated dosage of $0.506 \mathrm{~kg} \mathrm{ha}^{-1}$ (Figure 3 ).

The LNL was greater than $43 \mathrm{~g} \mathrm{~kg}^{-1}$ for all treatments (Figure 3). This value exceeds the sufficiency range for the bean crop, which varies from 30 to $35 \mathrm{~g} \mathrm{~kg}^{-1}$ (MARTINEZ; CARVALHO; SOUZA, 1999), and may be related to the topdressing of $45 \mathrm{~kg} \mathrm{~N} \mathrm{ha}^{-1}$.

In Figures 3 and 4, it can be seen that in those lots where the Mo was not applied together with the glyphosate, the LNL showed average values greater than $40 \mathrm{~g} \mathrm{~kg}^{-1}$. This value is greater than the sufficiency range for the proper development of the bean crop, which is from 30 to $35 \mathrm{~g} \mathrm{~kg}^{-1}$ (MARTINEZ; CARVALHO; SOUZA, 1999). In the treatment where there was no foliar application of Mo, application of

Table 3 - Number of grains per pod (GPP), 100-grain weight (W100G) and grain yield (GY) in a bean crop grown on brachiaria straw in 2009 and 2010, Coimbra, MG

\begin{tabular}{|c|c|c|c|c|c|c|}
\hline \multirow{3}{*}{ Year } & \multicolumn{2}{|c|}{ GPP } & \multicolumn{2}{|c|}{ W100G } & \multicolumn{2}{|c|}{ GY } \\
\hline & 2009 & 2010 & 2009 & 2010 & 2009 & 2010 \\
\hline & \multicolumn{2}{|c|}{ 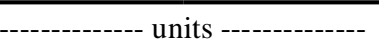 } & \multicolumn{2}{|c|}{---------- grams ----------- } & \multicolumn{2}{|c|}{ kg ha ${ }^{-1}$} \\
\hline Mean & $5.51 \mathrm{~B}$ & $5.98 \mathrm{~A}$ & $25.31 \mathrm{~A}$ & $24.42 \mathrm{~B}$ & $2.350 \mathrm{~A}$ & $1.873 \mathrm{~B}$ \\
\hline
\end{tabular}

Mean values accompanied by the same uppercase letter on a line do not differ statistically by F-test

Figure 2 - Levels of Mo in the leaves of bean plants as a function of dosages of Mo applied together with glyphosate in 2009 and 2010, Coimbra, MG

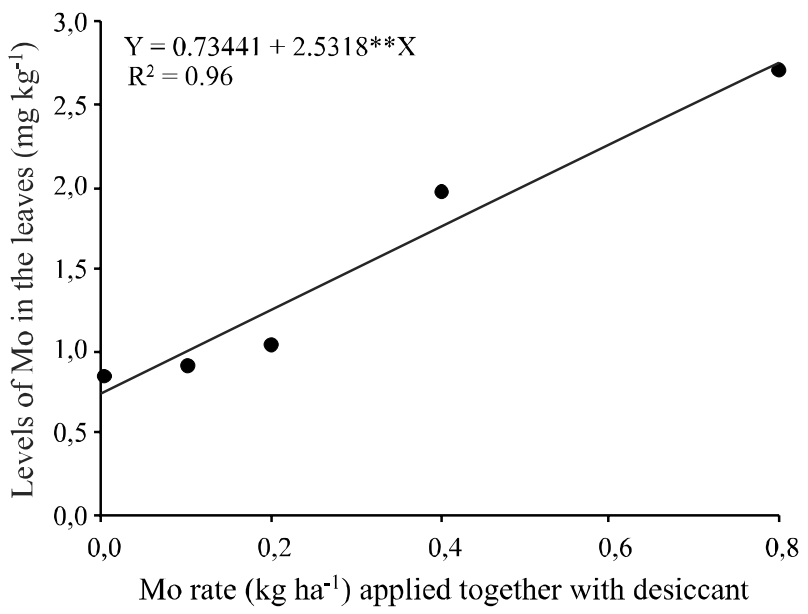

**Significant at $1 \%$
Figure 3 - Levels of $\mathrm{N}$ in the leaves of bean plants as a function of the application of dosages of Mo mixed with glyphosate in 2009 and 2010, Coimbra, MG

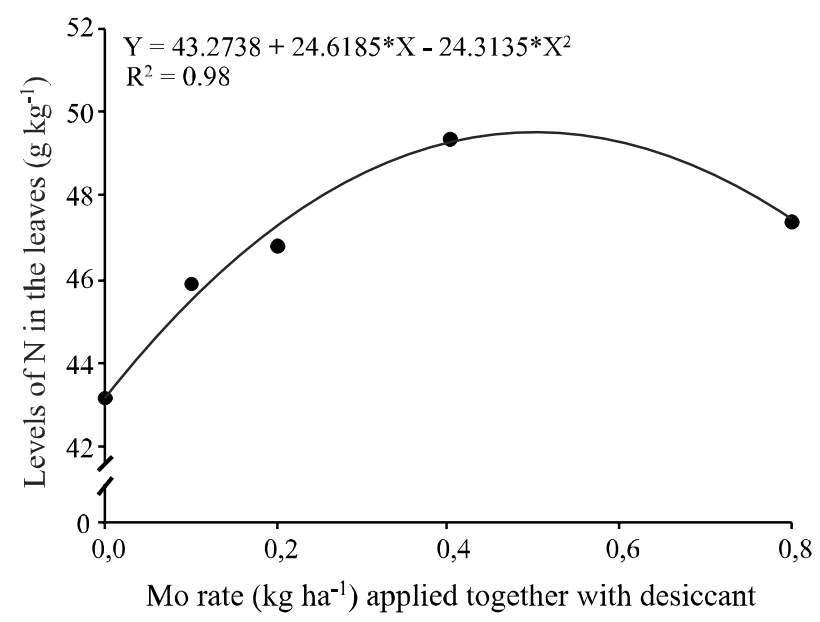

*Significant at $5 \%$ 
the Mo together with the glyphosate increased the LNL of the legume, which reached a maximum value of $50.5 \mathrm{~g} \mathrm{~N} \mathrm{~kg}^{-1}$ for an estimated dosage of $0.524 \mathrm{~kg} \mathrm{Mo} \mathrm{ha}^{-1}$ (Figure 4). With the application of $100 \mathrm{~g} \mathrm{Mo} \mathrm{ha}^{-1}$ via the leaves, an LNL was found of $46.9 \mathrm{~g} \mathrm{~kg}^{-1}$, remaining constant with the increase in dosages of Mo applied together with the herbicide (Figure 4). It can be seen that the dosages of Mo applied together with the glyphosate, and necessary to match the average levels of $\mathrm{N}$ in the leaves and grains obtained with the foliar application of $100 \mathrm{~g} \mathrm{Mo} \mathrm{ha}^{-1}$, were 0.199 and $0.207 \mathrm{~kg} \mathrm{ha}^{-1}$ respectively (Figures 4 and 7). Although these dosages are approximately twice that applied via the leaves, the benefits of the joint application of Mo and glyphosate should be considered, among them the lesser amount of machine traffic in the area, reducing soil compaction; the lower maintenance costs of the machinery and equipment; and the rationalisation of equipment and labour.

The increase in LNL can be explained by the Mo being directly related to $\mathrm{N}$ metabolism through its action on the enzymes nitrogenase and nitrate reductase. With an adequate supply of Mo, there is an improvement in the activity of these enzymes, enabling a better use of $\mathrm{N}$ by the bean plant (ARAÚJO et al., 2009; KUBOTA et al., 2008). On the other hand, part of the $\mathrm{N}$ accumulated in the leaves may also come from the decomposition of straw in previous years.

Comparing the years, the average value for LNL in 2010 was statistically higher than that in 2009 (Table 5).

For the levels of Mo in the grains (LMoG), in the interaction of Mo dosage applied together with glyphosate and the year, and regardless of the year, there was a linear increase seen in Mo levels as the dosages of Mo applied together with the desiccant were increased. However, the values obtained in the second year were always higher than in the first (Figure 5).

Considering that the experiment was carried out for a third consecutive year applying the treatments on the same sublots, the greater mean values seen in 2010 for the LMoG grown on brachiaria straw were probably due

Table 4 - Breakdown of the significant interactions in variance analysis, for Mo concentrations in the leaves (LMoL) and grains (LMoG) of a bean crop grown on brachiaria straw in 2009 and 2010, Coimbra, MG

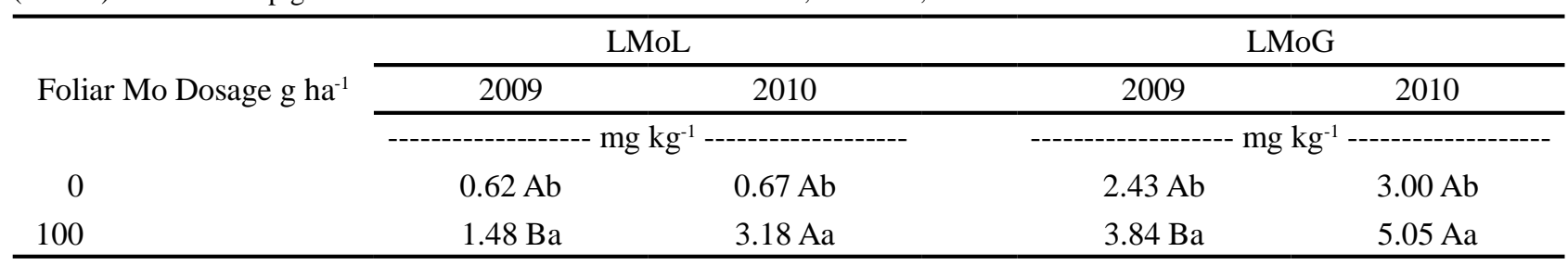

Mean values accompanied by the same uppercase letter on a line and lowercase letter in a column do not differ statistically by F-test

Figure 4 - Levels of $\mathrm{N}$ in the leaves of bean plants as a function of the application of dosages of Mo mixed with glyphosate, with and without Mo $\left(100 \mathrm{~g} \mathrm{ha}^{-1}\right)$ applied via the leaves, in 2009 and 2010, Coimbra- MG

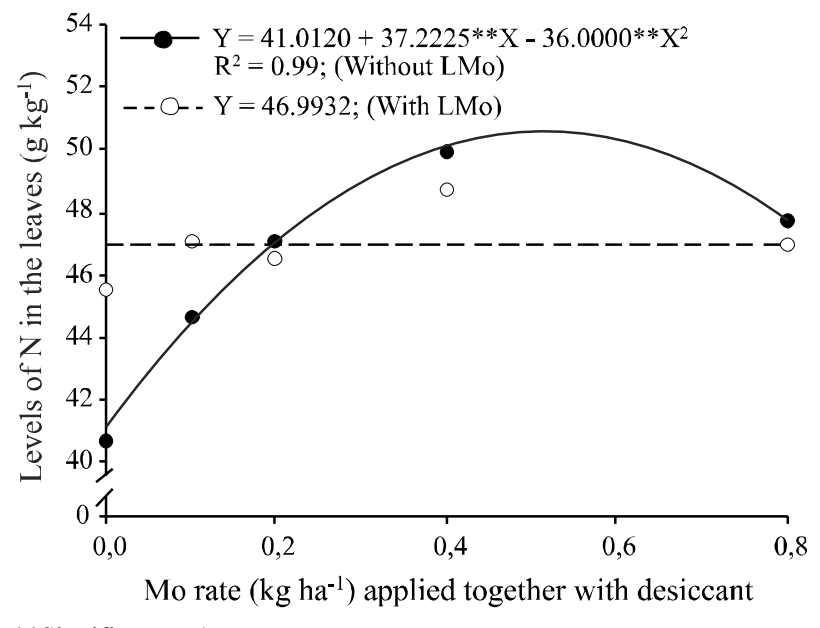

**Significant at $1 \%$
Figure 5 - Levels of Mo in the grains of bean plants as a function of the application of dosages of Mo mixed with glyphosate in 2009 and 2010, Coimbra-MG

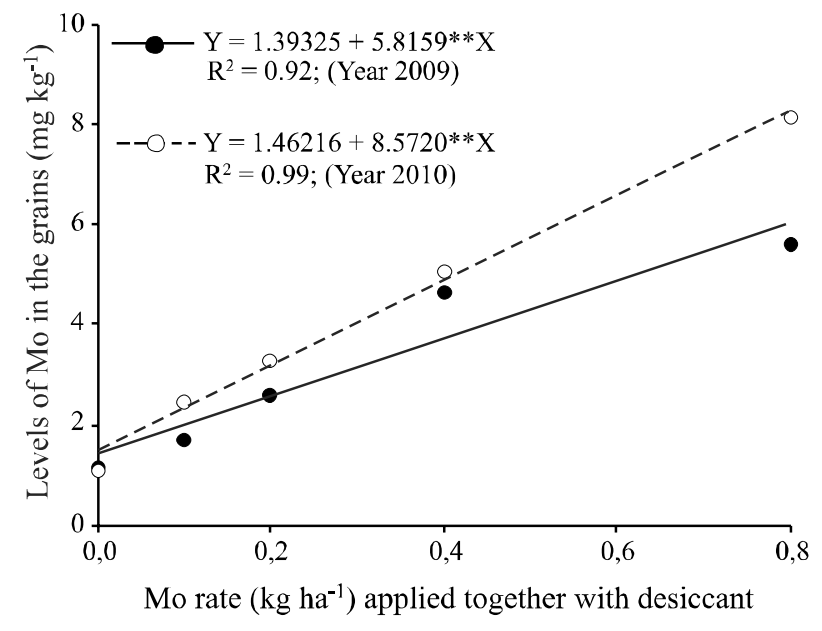

**Significant at $1 \%$ 
to the increased availability of residual Mo in a process of mineralization and from existing organic matter. This may contribute to the greater efficiency of molybdenum fertilization under DSS, keeping the micronutrient present for longer in the soil-plant system and resulting in lower losses of the Mo through fixation onto colloids in the soil.

The application of Mo together with the glyphosate caused linear increases in the concentrations of Mo in the grains, regardless of Mo being applied via the leaves or not (Figure 6). However, when $100 \mathrm{~g} \mathrm{Mo} \mathrm{ha}^{-1}$ were applied via the leaves, accumulation in the grains was greater than when there was no application. In addition, as the dosage of Mo applied together with the glyphosate increased, the difference in accumulation of the micronutrient in the grains showed a tendency to decrease, regardless of whether or not Mo was applied via the leaves.

These results demonstrate that the Mo applied together with the glyphosate used in the desiccation of the brachiaria was absorbed by the bean plant and translocated to the grains, and that foliar application of this micronutrient contributed even further to its accumulation in the grains (Figure 6). This capacity of the bean plant for accumulating Mo in the grains is, according to Jacob Neto and Rosseto (1998), an advantage for seed production, since in some cases the internal reserves of the seed can stimulate nitrogenase activity, increasing the accumulation of both biomass and $\mathrm{N}$ by the plant (KUBOTA et al., 2008).

When evaluating the effect of the interaction between the Mo dosage applied via the leaves and the year, it can be seen that the LMoG increased with the foliar application of $100 \mathrm{~g} \mathrm{Mo} \mathrm{ha}^{-1}$ regardless of the year. It was also seen that when the Mo was applied via the leaves, there was a significant increase in the LMoG for 2010 (Table 4).

In 2009, the levels of $\mathrm{N}$ in the grains of the bean plants was significantly higher than in 2010, which shows a decrease in LNG from one year to the other (Table 5).

For the interaction between the dosages of Mo applied with the glyphosate and the Mo applied via the leaves (Figure 7), it can be seen that with the application of $100 \mathrm{~g} \mathrm{Mo} \mathrm{ha}^{-1}$ via the leaves, the LNG remained

Table 5 - Levels of nitrogen in the leaves (LNL) and grains (LNG) of a bean crop grown on brachiaria straw in 2009 and 2010, Coimbra, MG

\begin{tabular}{|c|c|c|c|c|}
\hline \multirow{3}{*}{ Year } & \multicolumn{2}{|c|}{ LNL } & \multicolumn{2}{|c|}{ LNG } \\
\hline & 2009 & 2010 & 2009 & 2010 \\
\hline & \multicolumn{2}{|c|}{ 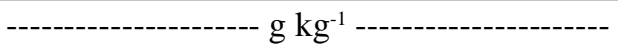 } & \multicolumn{2}{|c|}{ 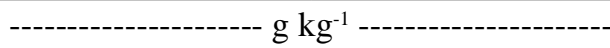 } \\
\hline Mean & $41.6 \mathrm{~B}$ & $51.4 \mathrm{~A}$ & $41.2 \mathrm{~B}$ & $35.5 \mathrm{~A}$ \\
\hline
\end{tabular}

Mean values accompanied by the same uppercase letter on a line do not differ statistically by F-test

Figure 6 - Levels of Mo in the grains of bean plants as a function of the application of dosages of Mo mixed with glyphosate, with and without Mo $\left(100 \mathrm{~g} \mathrm{ha}^{-1}\right)$ applied via the leaves, in 2009 and 2010, Coimbra-MG

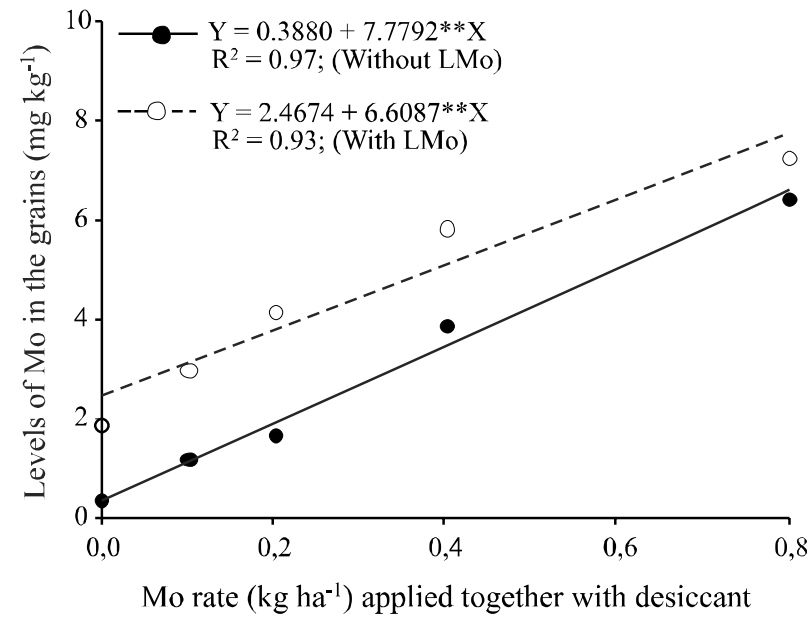

$* *$ Significant at $1 \%$
Figure 7 - Levels of $\mathrm{N}$ in the grains of bean plants as a function of the application of dosages of Mo mixed with glyphosate, with and without Mo (100 $\left.\mathrm{g} \mathrm{ha}^{-1}\right)$ applied via the leaves, in 2009 and 2010, Coimbra- MG

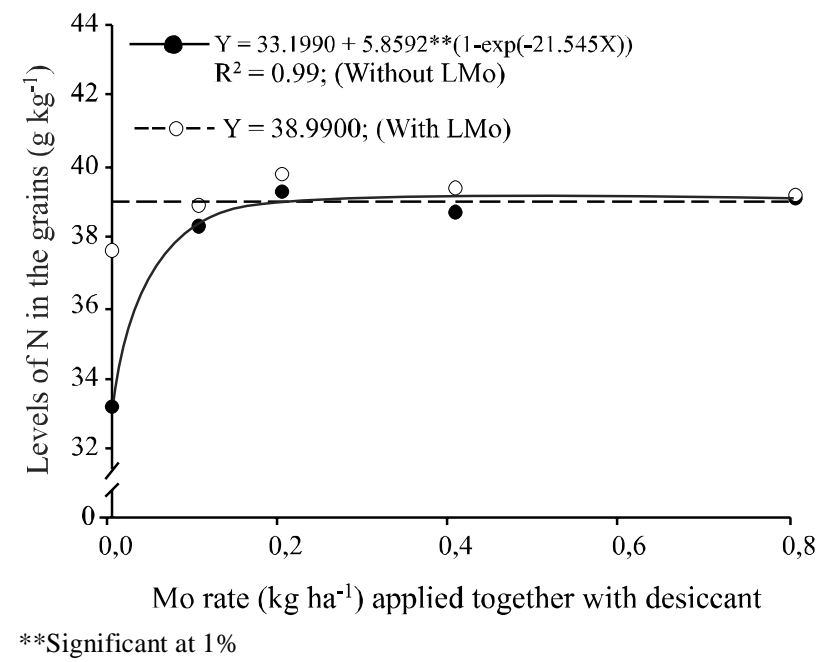


constant (with a mean value of $38.9 \mathrm{~g} \mathrm{~kg}^{-1}$ ). However, when there was no foliar application of Mo, the data fit the second Mitscherlich exponential model, requiring $0.207 \mathrm{~kg}$ Mo ha-1 to be applied mixed with the desiccant herbicide in order to equal the average level of $\mathrm{N}$ obtained with the foliar application of $100 \mathrm{~g} \mathrm{Mo} \mathrm{ha}^{-1}\left(38.9 \mathrm{~g} \mathrm{~kg}^{-1}\right)$.

At this dosage, the LNG remained constant with increasing dosages of Mo. The beginning of the curve explains the high response of the bean plant to fertilisation with Mo applied together with glyphosate, showing significant increases in LNG when using reduced dosages of the nutrient, reaffirming reports that Mo is required in very small amounts by the plants (MARSCHNER, 1995). These results show that the bean plants benefited nutritionally from the Mo applied together with the glyphosate, and that under such conditions there is no need for it to be applied via the leaves.

\section{CONCLUSIONS}

1. Yield components and grain productivity were not affected by the Mo when applied to the bean plant together with the glyphosate or via the leaves. However, there was a difference between variables when comparing results for the crop years;

2. The levels of Mo in the leaves and grains of the bean plant increase as the dosage of Mo applied together with the glyphosate increases, being more marked when complemented by the foliar application of Mo;

3. The application of Mo together with the desiccant over the years, favours the absorption and accumulation of Mo in the grains;

4. The levels of foliar nitrogen increased with the application of Mo mixed with the desiccant, dispensing with application of the Mo via the leaves.

\section{ACKNOWLEDGEMENTS}

The authors wish to thank CNPq and FAPEMIG for their financial support.

\section{REFERENCES}

ALBUQUERQUE, H. C. et al. Capacidade nodulatória e características agronômicas de feijoeiros comuns submetidos à adubação molíbdica parcelada e nitrogenada. Revista Ciência Agronômica, v. 43, n. 2, p. 214-221, 2012.

ARAÚJO, G. A. A. et al. Misturas de herbicidas com adubo molíbdico na cultura do Feijão. Planta Daninha, v. 26, n. 1, p. $237-247,2008$.
ARAÚJO, P. R. A. et al. Combinações de doses de molibdênio e nitrogênio na adubação da cultura do feijoeiro-comum. Acta Scientiarum. Agronomy, v. 31, n. 2, p. 227-234, 2009.

ASCOLI, A. A. et al. Aplicação foliar de molibdênio, produtividade e qualidade fisiológica de sementes de feijoeiro irrigado. Bragantia, v. 67, n. 2, p. 377-384, 2008.

CALONEGO, J. C. et al. Adubação nitrogenada em cobertura no feijoeiro com suplementação de molibdênio via foliar. Revista Ciência Agronômica, v. 41, n. 3, p. 334-340, 2010.

CASQUERO, P. A. et al. Performance of common bean (Phaseolus vulgaris L.) landraces from Spain in the Atlantic and Mediterranean environments. Genetic Resources and Crop Evolution, v. 53, n. 5, p.1021-1032, 2006.

DAMATO NETO, J. Resposta do feijoeiro ao molibdênio em mistura com glyphosate no plantio direto. 2010. $46 \mathrm{f}$. Dissertação (Mestrado em Fitotecnia) - Universidade Federal de Viçosa, Viçosa, MG, 2010.

DECHEN, A. R.; NACHTIGALL, G. R. Elementos requeridos à nutrição de plantas. In: NOVAIS, R. F. et al. (ED.). Fertilidade do Solo. Viçosa: SBCS/UFV, 2007. p. 92-132.

EMPRESABRASILEIRADEPESQUISAAGROPECUÁRIA. Centro Nacional de Pesquisa de Solos. Sistema Brasileiro de Classificação de Solos. 2.ed. Rio de Janeiro, 2006. 306 p.

FERREIRA, A. C. B. et al. Características agronômicas do feijoeiro em função do molibdênio contido na semente e da sua aplicação via foliar. Acta Scientiarum. Agronomy, v. 25, n. 1, p. 65-72, 2003.

JACOB NETO, J.; ROSSETO, C. A. V. Concentração de nutrientes nas sementes: o papel do molibdênio. Floresta $\mathrm{e}$ Ambiente, v. 5, n. 1, p. 171-183, 1998.

KUBOTA, F. Y. et al. Crescimento e acumulação de nitrogênio de plantas de feijoeiro originadas de sementes com alto teor de molibdênio. Revista Brasileira de Ciência do Solo, v. 32, n. 4, p. 1635-1641, 2008

LEITE, U. T. et al. Rendimento de grãos e componentes de rendimento do feijoeiro em função da aplicação foliar de doses crescentes de molibdênio. Acta Scientiarum. Agronomy, v. 29, n. 1, p. 113-120, 2007.

MAlAVOlTA, E. A.; VITTI, G. C.; OLIVEIRA, A. S. Avaliação do estado nutricional das plantas: princípios e aplicações. Piracicaba: Potafos, 1997. 201 p.

MARSCHNER, H. Mineral nutrition of higher plants. San Diego: Academic Press, 1995. 889 p.

MARTINEZ, H. E. P.; CARVALHO, J. G.; SOUZA, R. B. Diagnose foliar. In: RIBEIRO, A. C.; GUIMARÃES, P. T. G.; ALVAREZ V., V. H. Recomendações para o uso de

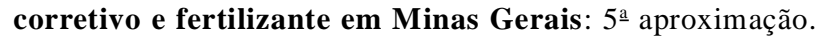
Viçosa, MG, 1999. p. 143-168.

NUNES, U. R. et al. Produção de palhada de plantas de cobertura e rendimento do feijão em plantio direto. Pesquisa Agropecuária Brasileira, v. 41, n. 6, p. 943-948, 2006.

OLIVEIRA, I. P.; THUNG, M. D. T. Nutrição mineral. In: ZIMMERMANN, M. J. O.; ROCHA, M.; YAMADA, T. (Ed.). 
Cultura do feijoeiro: fatores que afetam a produtividade. Piracicaba: Potafos, 1988. p. 175-212.

PESSOA, A. C. S. et al. Concentração foliar de molibdênio e exportação de nutrientes pelo feijoeiro "Ouro Negro" em resposta à adubação foliar com molibdênio. Revista Brasileira de Ciência do Solo, v. 24, p. 75-84, 2000.

PIANA, C. F. B.; SILVA, J. G. C.; ANTUNES, I. F. Ajuste do rendimento para a variação do estande em experimentos de melhoramento genético do feijão. Pesquisa Agropecuária Brasileira, v. 42, n. 12, p. 1687-1696, 2007.

PIRES, A. A. et al. Rendimento de grãos, componentes do rendimento e índice spad do feijoeiro (Phaseolus vulgaris 1.) em função de época de aplicação e do parcelamento da aplicação foliar de molibdênio. Ciência e Agrotecnologia, v. 28, n. 5 , p. 1092-1098, 2004.

RIBEIRO, N. D. et al. Alterações em caracteres agromorfológicos em função da densidade de plantas em cultivares de feijão. Revista Brasileira de Agrociência, v.10, n. 2, p. 167-173, 2004.

SAS INSTITUTE INC. SAS system for windows. Version 9.1. Cary: SAS Institute. 2003. 2 CD-ROMs.

SCHWARZ, G.; MENDEL, R. R.; RIBBE, M.W. Molybdenum cofactors, enzymes and pathways. Nature, v. 460, n. 7257, p. $839-847,2009$.

VIEIRA, R. F. et al. Conteúdo de molibdênio das sementes de feijoeiro em resposta a doses do micronutriente pulverizado sobre as plantas. Ciência Rural, v. 40, n. 3, p. 666-669, 2010. 